\title{
The Effect of Sambung Nyawa Leaf Extract (Gynura procum- bens (Lour.) Merr.) on Hemoglobin of Rats Induced by Escherichia coli Bacteria
}

\author{
Asnad Gulo ${ }^{a}$ and Pasar M Silitonga ${ }^{a}$ \\ a Department of Chemistry, Faculty of Mathematics and Natural Sciences, Universitas Negeri Medan, Jl. Willem \\ Iskandar Pasar V Medan Estate, Medan 20221, Indonesia
}

*Email: asnadgulo14@yahoo.com

\section{ABSTRACT}

The aim of this research was to study the effect of extract of the sambung nyawa (Gynura procumbens (Lour.)Merr.)) leaf on hemoglobin concentration of rats blood. The research method is experimental used Completely Randomized Design (CRD) that consists of 6 treatments and 3 replications. The treatment of this research was induced rats with E. coli then given $0.5 \mathrm{~mL}$ of sambung nyawa leaf extract with doses $0.0 \mathrm{mg} / \mathrm{kgBW}$; $300 \mathrm{mg} / \mathrm{kgBW} ; 600 \mathrm{mg} / \mathrm{kgBW}$ and $900 \mathrm{mg} / \mathrm{kgBW}$. The data was analyzed using Analysis of Variance. The results showed that the giving extract of the sambung nyawa leaves gives effect on on hemoglobin concentration of rats blood. Giving sambung nyawa leaf extract at dose $0.00 \mathrm{mg} / \mathrm{kgBW} ; 300 \mathrm{mg} / \mathrm{kgBW} ; 600 \mathrm{mg} / \mathrm{kgBW}$ and 900 $\mathrm{mg} / \mathrm{kgBW}$ to rats gave the average of hemoglobin concentration in a row in each treatment is $10,5 \mathrm{~g} / \mathrm{dL} ; 11,7$ $\mathrm{g} / \mathrm{dL} ; 12,3 \mathrm{~g} / \mathrm{dL}$ and $13,7 \mathrm{~g} / \mathrm{dL}$.

Keywords: sambung nyawa leaf, diarrhea, Escherichia Coli, hemoglobin

\section{Pendahuluan}

Tanaman Sambung nyawa (Gynura procumbens(Lour.)Merr.) merupakan tanaman obat yang dapat dimanfaatkan sebagai bahan baku industri farmasi. Daun sambung nyawa berasal dari Afrika yang banyak tumbuh di benua Afrika bagian barat terutama di Nigeria dan negara yang beriklim termasuk negara Indonesia. Pada tahun 2009 di Bogor, telah dilakukan pembudidayaan tanaman daun sambung nyawa. Tanaman ini mudah tumbuh pada daerah yang mempunyai curah hujan cukup tinggi sehingga bisa tumbuh dengan baik di Indonesia. Tanaman ini termasuk dalam famili Asteraceae, merupakan tanaman menahun. Tanaman ini memiliki tinggi sekitar 3 meter atau lebih, bentuk dari batangnya yaitu bersegi dan tekstur lunak serta memiliki air di batang. Daun dari tanaman ini ber- warna hijau muda serta memiliki bentuk bulat seperti telur, panjang daunnya mencapai $6 \mathrm{~cm}$ dan lebar 3,5 cm. Ujung dari daun berbentuk runcing. ${ }^{1}$ Hasil penelitian Aryanti dkk, daun sambung nyawa (Gynura procumbens(Lour.)Merr.) dapat dimanfaatkan sebagai antibakteri terhadap beberapa bakteri diantaranya S.aureus, E.coli dan S.typhimurim ${ }^{2}$. Alkaloid yang terkandung dalam daun sambung nyawa mempunyai aktivitas sebagai antibakteri dengan mengganggu fungsi metabolisme melalui kerusakan dinding sel dan mendenaturasi protein bakteri. Sedangkan saponin memiliki aktivitas antibakteri dengan mengganggu permukaan dinding sel, saat terganggu akan dengan mudah masuk kedalam sel bakteri ${ }^{3}$. Ekstrak daun sambung nyawa dapat menghambat pertumbuhan 
Escherichia coli, yang merupakan bakteri gram negatif yang dapat menyebabkan diare. Adanya zona penghambatan pada ekstrak daun sambung nyawa terhadap bakteri Escherichia coli tersebut mengindikasikan bahwa dalam ekstrak tersebut terdapat senyawa aktif didapatkan seperti senyawa fenol, steroid dan saponin. Senyawa fenol dan saponin memiliki mekanisme dalam menghambat pertumbuhan bakteri. ${ }^{4}$

Salah satu penyakit yang termasuk banyak dialami oleh masyarakat Indonesia yaitu penyakit diare disebabkan karena morbiditas dan mortalitasnya yang masih tinggi serta lingkungan yang tidak higenis. Di negara berkembang, Penyebab diare terbanyak kedua setelah rotavirus adalah infeksi karena bakteri Escherichia coli. Escherichia coli merupakan bakteri komensal, patogen intestinal dan patogen ekstraintestinal menyebabkan infeksi traktus urinarius, meningitis, dan septicemia. ${ }^{5}$ Infeksi bakteri Escherichia coli sebagai penyebab diare dapat mengakibatkan penurunan kadar haemoglobin. Berdasarkan penelitian Sackey dkk, menemukan bahwa anak-anak yang menderita diareakibat infeksi bakteri secara signifikan mengurangi kadar haemoglobin rata-rata dibandingkan dengan anak-anak yang tidak terinfeksi. Data mereka menunjukkan bahwa infeksi G.lamblia memiliki dampak buruk pada pertumbuhan linier anak dan kadar haemoglobin. Bakteri patogen dapat merusak permeabilitas membran sel dan akan berakhir dengan rusaknya dinding sel, sehingga berakibat keluarnya haemoglobin dari sel dan menurunkan kadar haemoglobin. Diare dapat menyebabkan stres sehingga serotonin akan teraktivasi dan menstimulasi terjadinya peningkatan kerja dari HPA Axis, kortisol dan gaster. Peningkatan kerja gaster akan mengakibatkan sekresi berlebih dari $\mathrm{HCl}$ yang dikeluarkan oleh sel parietal sehingga akan terjadi peningkatan asam lambung, peningkatan asam lambung inilah yang akan merusak kompleks heme. Kapasitas haemoglobin dalam mengikat oksigen bergantung pada gugus heme. Gugus heme yang menyebabkan darah berwarna merah. Gugus heme terbentuk dari komponen anorganik dan pusat atom besi. ${ }^{6}$ Kehilangan besi disebabkan oleh penyakit kronis, infeksi dari penyakit ini dapat menyebabkan pembentukan haemoglobin darah terlalu lambat .

Penyakit diare dan ISPA dapat mengganggu nafsu makan yang akhirnya dapat menurunkan tingkat konsumsi gizi termasuk besi yang berperan dalam pembentukan haemoglobin jadi semakin rendah asupan zat besi dalam tubuh maka semakin rendah juga kadar haemoglobin. Besi memiliki fungsi dalam mengatasi infeksi pada tubuh. Jika tubuh kekurangan besi akan meningkatkan infeksi serta imun menurun. Disentri ataupun yang dikenal dengan diare akut yang disertai dengan lendir dan darah juga sangat berpengaruh dalam penurunan kadar haemoglobin pasien diare akut. Disentri pada umumnya diakibatkan karna adanya infeksi oleh Shigella sp yang kemudian menginvasi epitel selaput lendir, mikroabses pada dinding usus besar dan ileum terminal yang cenderung mengakibatkan perdarahan pada daerah ulkus. ${ }^{6}$

\section{Metodologi Penelitian}

\subsection{Bahan Kimia, Peralatan dan Instrumentasi}

18 ekor tikus putih jantan dewasa berumur 2-3 bulan dengan berat badan 130-170 gram, pelet standar dan air putih, ekstrak daun sambung nyawa, etanol $\left(\mathrm{C}_{2} \mathrm{H}_{5} \mathrm{OH}\right) 96 \%$, asam klorida $(\mathrm{HCl}) 2 \mathrm{~N}$, aquadest $\left(\mathrm{H}_{2} \mathrm{O}\right)$, pereaksi mayer, pereaksi wagner, asam asetat anhidrat $\left(\mathrm{CH}_{3} \mathrm{CO}\right)_{2} \mathrm{O}$, asam sulfat pekat $\left(\mathrm{H}_{2} \mathrm{SO}_{4}\right)$,serbuk magenisum( $\left.\mathrm{Mg}\right)$, asam klorida (HCl) $2 \%$, pereaksi besi (III) klorida $\left(\mathrm{FeCl}_{3}\right) 1 \%$, air panas, Mueller Hinton Agar (MHA), natrium klorida $(\mathrm{NaCl})$ 0,9\%, alkohol 70\%, bakteri E. coli, feroglobin, adalah seperangkat alat destilasi, botol gelap, blender, ayakan mesh 60, botol maserasi, corong buchner, vakum, kertas saring, erlenmeyer, gelas kimia, rotary evapotator, hot plate, aluminium foil,timbangan analitik, pipet tetes, gelas ukur, corong kaca, kaca arloji, tabung reaksi, rak tabung reaksi, labu ukur, sudip, autoklaf, cawan petri, jarum ose, laminar flow, kandang tikus putih, oral sonde, spuit, gunting bengkok, tabung EDTA $3 \mathrm{cc}$, dan spektrofotometer.

\subsection{Prosedur Penelitian}

\section{Ekstraksi daun sambung nyawa}

Tanaman daun sambung nyawa yang digunakan dalam penelitian ini diperoleh dari Kuala Tanjung, Kabupaten Batu Bara, Sumatera Utara. Sampel yang diambil sebanyak $5 \mathrm{~kg}$ dengan memilih daun dewasa dan segar. Hal ini bertujuan untuk menjamin mutu dan kualitas dari sampel daun yang akan digunakan dalam penelitian. Determinasi tanaman dilakukan di Herbarium Medanense Universitas Sumatera Utara.

Daun sambung nyawa yang telah dikumpulkan, dicuci bersih untuk memisahkan kotoran dari sampel, dipotong-potong menjadi kecil, lalu dike- 
ringkan dengan cara diangin-anginkan sampai kering. Setelah daun kering, dihaluskan menggunakan blender dan diayak menggunakan pengayak mesh 60 hingga diperoleh serbuk halus. Serbuk halus yang didapatkan sebanyak 950 gram dimasukkan kedalam botol maserasi. Sampel diekstraksi dengan metode maserasi dengan pelarut etanol 96\% setelah selesai maserasi hasil ekstrak yang didapat dipekatkan dengan rotary evaporator.

\section{Skrining Fitokimia}

\section{Uji Senyawa Golongan Alkaloid}

Uji keberadaan senyawa golongan alkaloid dilakukan dengan menambahkan 0,5 gram sampel dengan $1 \mathrm{~mL} \mathrm{HCl} 2 \mathrm{~N}$ dan ditambahkan dengan 9 $\mathrm{mL}$ aquades selanjutnya ditambahkan dengan 5 tetes pereaksi dragendorff, adanya endapan merah bata menandakan adanya golongan alkaloid

Uji alkaloid dilakukan dengan metode Mayer dan Wagner. Sampel sebanyak $3 \mathrm{~mL}$ diletakkan dalam cawan porselen kemudian ditambahkan 5 $\mathrm{mL} \mathrm{HCl} 2 \mathrm{~N}$ dan $5 \mathrm{~mL}$ aquadest, lalu dipanaskan di atas penangas air selama 2 menit. Dinginkan sampel pada temperatur kamar dan disaring. Filtrat yang diperoleh dibagi 3 bagian A, B, dan C. Filtrat A sebagai blanko, filtrat B ditambah pereaksi Mayer, reaksi positif jika terbentuk endapan menggumpal berwarna putih atau kuning. Sedangkan filtrat C ditambah pereaksi Wagner, reaksi positif ditandai dengan terbentuknya endapan berwarna coklat. ${ }^{8}$

\section{Uji Senyawa Golongan Flavonoid}

Pemeriksaan flavanoid dilakukan dengan mereaksikan ekstrak dari hasil maserasi dengan serbuk $\mathrm{Mg}$ sebanyak 0,1 mg dan 4 tetes $\mathrm{HCl}$ 2\%. Keberadaan flavanoid akan ditunjukkan dengan terjadinya perubahan warna filtrat menjadi jingga-merah. ${ }^{9}$

Uji keberadaan senyawa golongan flavonoid dilakukan dengan menambahkan dua tetes larutan $\mathrm{FeCl}_{3} 5 \%$ pada lima tetes sampel diplat tetes. terjadinya perubahan warna kehijauan atau hitam biru menunjukkan adanya flavonoid.

\section{Uji Senyawa Golongan Saponin}

Sebanyak $1 \mathrm{~mL}$ ekstrak dimasukkan ke dalam tabung reaksi, ditambahkan $10 \mathrm{~mL}$ aqudest, didinginkan, dikocok 10 detik. Jika terbentuk buih selama kurang lebih 10 menit, setinggi $1-10 \mathrm{~cm}$ dan tidak hilang jika ditambahkan 1 tetes $\mathrm{HCl} 2 \mathrm{~N}$ maka menunjukan adanya saponin.$^{10}$

\section{Uji Senyawa Golongan Steroid/Triterpenoid}

Untuk identifikasi senyawa steroid dan triterpenoid dilakukan dengan mereaksikan ekstrak sebanyak 0,5 gram dengan 10 tetes asam asetat anhidrat, lalu diaduk secara perlahan beberapa saat sampai kering, kemudian ditambahkan 1-2 tetes asam sulfat pekat. Terbentuknya warna merah atau ungu menandakan adanya senyawa triterpenoid dan terbentuknya warna hijau-biru menandakan adanya steroid. ${ }^{9}$

\section{Uji Senyawa Golongan Tanin}

Sebanyak 0,5 gram sampel ditambahkan dengan 10 mLaquadest dan ditambah $\mathrm{FeCl}_{3} 1 \%$ Jika terjadi warna biru kehitaman atau hijau kehitaman menunjukkan adanya tannin. ${ }^{8}$

Pada penelitian digunakan 18 ekor tikus putih jantan yang dibagi menjadi 6 kelompok perlakuan. Semua tikus percobaan diadaptasikan selama 7 hari. Tahap selanjutnya tikus dipuasakan selama 16-18 jam sebelum perlakuan (tidak makan tetapi tetap diberi minum), tujuannya untuk menyamakan keadaan tikus, mencegah pengaruh dari makanan yang dikonsumsi sehingga tidak menganggu proses absorbsi. Pengambilan darah awal tikus putih dilakukan dengan memotong ekornya yang terlebih dahulu diulas dan dibersihkan menggunakan alkohol 70\% dan ditampung dalam tabung EDTA untuk mengukur kadar haemoglobin sebelum perlakuan. Setelah pengambilan darah semua tikus dipuasakan selama 60 menit lalu diinduksi dengan bakteri Escherichia coli ATCC 259220.5 mL/ekor secara oral, setelah terjadi diare pada tikus putih maka dilakukan pengambilan darah tikus putih dengan memotong ekor setelah terlebih dahulu diulas dan dibersihkan menggunakan alkohol 70\% dan ditampung dalam tabung reaksi yang sudah diberi antikoagulan (EDTA) untuk mengukur kadar haemoglobin setelah diinduksi bakteri Escherichia coli.

Setelah 30 menit setelah diinduksi bakteri Escherichia coli, tikus putih diberi perlakuan ekstrak daun sambung nyawa sesuai dosis perlakuan yang telah ditentukan dan diberikan dengan cara mencekok. Kelompok I tikus yang tidak diinduksi bakteri Escherichia coli, kelompok II tikus diinduksi dengan bakteri Escherichia coli dan tidak diberikan ekstrak daun sambung nyawa sebagai kontrol negatif, Kelompok III tikus diinduksi dengan bakteri Escherichia coli dan setelah diare diberikan feroglobin dengan dosis 0,2 $\mathrm{mL} / \mathrm{kgBB}$ sebagai kontrol positif, kelompok IV tikus diinduksi dengan bakteri Escherichia coli dan setelah diare diberikan dosis ekstrak daun sambung nyawa $300 \mathrm{mg} / \mathrm{kgBB}$, dan kelompok $\mathrm{V}$ tikus diinduksi dengan bakteri Escherichia coli dan 
setelah diare diberikan dosis ekstrak daun sambung nyawa $600 \mathrm{mg} / \mathrm{kgBB}$, kelompok VI tikus diinduksi dengan bakteri Escherichia coli dan setelah diare diberikan dosis ekstrak daun sambung nyawa 900 $\mathrm{mg} / \mathrm{kgBB}$.Pemberian ekstrak sebanyak 0,5 mL/ekor dan feroglobin $0,2 \mathrm{~mL} /$ ekor yang diberikan secara oral.

Pengamatan terhadap tikus putih dilakukan saat mulai terjadinya diare. Untuk mengetahui berapa lama diare terjadi setelah suntikan bakteri Escherichia coli sampai feses kembali normal maka ditentukan rentang waktu diare. Rentang waktu diare dihitung dengan cara mengurangkan waktu terbentuknya feses kembali normal dengan waktu saat mulai terjadinya diare. Setelah tikus sudah tidak diare maka dilakukan pengambilan darah untuk pengukuran kadar haemoglobin darah. Pengambilan darah dilakukan dengan memotong ekor tikus setelah terlebih dahulu diulas dan dibersihkan menggunakan alkohol 70\% dan ditampung dalam tabung reaksi yang sudah diberi antikoagulan (EDTA). Penentuan kadar haemoglobin darah dilakukan dengan metode sianmethaemoglobin.

\section{Hasil dan Diskusi}

3.1. Hasil Ekstraksi Daun Sambung Nyawa dan Skrining Fitokimia

Hasil pembuatan simplisia serbuk daun sambung nyawa dalam penelitian ini sebanyak 950 gram berwarna hijau kecoklatan, bau khas, memiliki rendemen sebesar 13,8\%.

Tabel 1. Hasil skrining fitokimia ekstrak etanol daun sambung nyawa(gynura procumbens(lour.)merr.)

\begin{tabular}{|c|c|c|}
\hline $\begin{array}{c}\text { UJI } \\
\text { FITOKIMIA }\end{array}$ & $\begin{array}{l}\text { INDIKATOR UJI } \\
\text { POSITIF }\end{array}$ & $\begin{array}{c}\text { HASIL } \\
\text { UJI }\end{array}$ \\
\hline \multirow[t]{3}{*}{ Alkaloid } & $\begin{array}{l}\text { Endapan merah bata } \\
\text { (dragendroff) }\end{array}$ & - \\
\hline & Endapan coklat (wagner) & + \\
\hline & $\begin{array}{l}\text { Endapan putih atau kuning } \\
\text { (mayer) }\end{array}$ & - \\
\hline \multirow[t]{2}{*}{ Flavonoid } & $\begin{array}{l}\text { Kehijauan atau biru hitam } \\
\left(\mathrm{FeCl}_{3} 5 \%\right)\end{array}$ & ++++ \\
\hline & $\begin{array}{l}\text { Jingga merah (Serbuk Mg } \\
+\mathrm{HCl} 2 \% \text {.) }\end{array}$ & +++ \\
\hline Saponin & Aquadest & ++++ \\
\hline Steroid & Asetat anhidrat & ++++ \\
\hline Terpenoid & Asetat anhidrat & - \\
\hline Tanin & $\mathrm{FeCl}_{3} 1 \%$ & ++++ \\
\hline
\end{tabular}

Hasil positif alkaloid pada pereaksi wagner menunjukkan hasil positif pada ekstrak daun sambung nyawa dengan ditandai adanya endapan coklat, diperkirakan endapan coklat tersebut adalah kalium-alkaloid. dalam pembuatan pereaksi wagner, iodine akan bereaksi dengan ion $\mathrm{I}^{-}$dari kalium iodide menghasilkan ion $\mathrm{I}^{3-}$ yang berwarna coklat. Pada pengujian alkaloid menggunakan pereaksi wagner, ion logam $\mathrm{K}^{+}$membentuk ikatan kovalen koordinat dengan nitrogen pada alkaloid sehingga terbentuk kompleks kalium-alkaloid yang mengendap $^{11}$.

Uji Flavonoid dapat diuji juga dengan mengambil ekstrak daun sambung nyawa sebanyak 2 $\mathrm{mL}$ dan kemudian dilakukan pemanasan selama kurang lebih 5 menit. Setelah pemanasan dilakukan, selanjutnya menambahkan 0,1 gram serbuk logam magnesium pada ekstrak dan kemudian menambahkan tetes demi tetes larutan $\mathrm{HCl} 2 \%$. Hasil yang didapatkan pada ekstrak etanol terbentuk warna jingga merah hal ini menandakan adanya senyawa flavonoid pada sampel daun sambung nyawa. Penambahan logam $\mathrm{Mg}$ dan $\mathrm{HCl}$ bertujuan untuk mereduksi inti benzopiron yang terdapat dalam struktur flavonoid sehingga terbentuk garam flavilium berwarna merah atau jingga ${ }^{12}$.

Identifikasi saponin dilakukan dengan menambahkan $10 \mathrm{~mL}$ aquadest pada $1 \mathrm{~mL}$ sampel lalu dikocok selama 10 menit menghasilkan busa konstan dan ketika ditambahkan 3-5 tetes $\mathrm{HCl} 2 \mathrm{~N}$ busanya tidak hilang sehingga menandakan adanya senyawa saponin. Pada percobaan ini menunjukkan hasil positif dengan tetap menghasilkan busa ketika penambahan $\mathrm{HCl} 2 \mathrm{~N}$. Saponin ketika dikocok akan terbentuk busa atau buih yang disebabkan karena terdapat gugus hidrofil yang berikatan dengan air sedangkan hidrofob akan berikatan dengan udara. ${ }^{13}$

Identifikasi steroid dilakukan dengan menambahkan 10 tetes asetat anhidrat pada 0,5 gram ekstrak daun sambung nyawa selanjutnya ditambahkan 2 tetes asam sulfat pekat dikocok dan dibiarkan beberapa menit dan timbulnya warna hijau dan biru menunjukkan positif mengandung steroid dan negatif terpenoid. Hal ini didasari oleh kemampuan senyawa steroid membentuk warna oleh $\mathrm{H}_{2} \mathrm{SO}_{4}$ dalam pelarut asam asetat anhidrid. ${ }^{14}$

Identifikasi tanin dilakukan dengan menambahkan 0,5 gram ekstrak etanol daun sambung nyawa dengan 3 tetes $\mathrm{FeCl}_{3} \quad 1 \%$ maka timbulnya warn hijau kehitaman yang menandakan positif mengandung tanin. Hasil dari percobaan ini terjadi perubahan warna menjadi warna hijau kehitaman yang menandakan positif tanin. 
Terbentuknya senyawa kompleks antara tanin dan $\mathrm{Fe}^{3+}$ yang memberikan perubahan warna menjadi hijau kehitaman. Uji fitokimia dengan menggunakan $\mathrm{FeCl}_{3}$ digunakan untuk menentukan apakah sampel mengandung gugus fenol. adanya gugus fenol ditandai dengan warna hijau kehitaman atau biru tua setelah penambahan $\mathrm{FeCl}_{3}$, apabila uji fitokimia dengan $\mathrm{FeCl}_{3}$ memberikan hasil positif diduga dalam sampel terdapat senyawa fenol dan salah satu senyawa fenol yaitu tanin. Terbentuknya warna hijau kehitaman atau biru tinta pada ekstrak setelah ditambahkan dengan $\mathrm{FeCl}_{3}$ disebabkan karena tanin akan membentuk senyawa kompleks dengan ion $\mathrm{Fe}^{3+15}$.

\subsection{Rentang Waktu Diare}

Hasil penelitian menunjukkan bahwa tikus putih yang diinduksi dengan bakteri E.coli dan diberi ekstrak daun sambung nyawa (Gynura Procumbens) dengan dosis yang bervariasi memiliki rentang waktu diare yang berbeda-beda. Tikus yang diberi ekstrak daun sambung nyawa dengan dosis $0,0 \mathrm{mg} / \mathrm{Kg} \mathrm{BB}$ memiliki rentang waktu diare yang paling lama yaitu 240 menit. Selanjutnya,tikus yang diberi ekstrak daun sambung nyawa dengan dosis $300,0 \mathrm{mg} / \mathrm{Kg} \mathrm{BB}$ memiliki rentang waktu diare 180 menit, diberi 600 $\mathrm{mg} / \mathrm{Kg}$ BB mempunyai rentang waktu diare 120 menit yang merupakan rentang waktu paling singkat,kemudian dosis $900 \mathrm{mg} / \mathrm{Kg} \mathrm{BB}$ memiliki rentang waktu diare 80 menit dan kontrol positifnya(feroglobin) adalah 70 menit.

\subsection{Hasil Analisis Kadar Haemoglobin Tikus Putih}

Hasil analisis kadar hemoglobin darah pada awal percobaan (sebelum diberikan perlakuan) pada tikus yang tidak diinduksi dengan E.coli menunjukkan bahwa rataan kadar hemoglobin darah sebesar 12,43 gr/dL, sedangkan pada tikus putih yang akan diinduksi dengan E.coli tapi diberi Feroglobin diperoleh rataan kadar hemoglobin sebesar 13,3 gr/dL. Pada tikus putih yang akan diinduksi dengan E.coli dan diberi Ekstrak Daun Sambung Nyawa dengan dosis 0,$0 ; 300 ; 600$ dan $900 \mathrm{mg} / \mathrm{kgBB}$ diperoleh rataan kadar hemoglobin darah berturut-turut sebesar 13,$06 ; 12,73 ; 12,16$ dan 12,0 gr/dL. Artinya semua tikus dalam keadaan kadar $\mathrm{Hb}$ yang normal.

Setelah tikus putih diinduksi dengan bakteri Escherichia coli ATCC $259220.5 \mathrm{~mL}$ /ekor secara oral dan kondisinya diare, maka terjadi penurunan kadar hemoglobin hingga dibawah kadar normal. Penurunan kadar haemoglobin pada kondisi diare terjadi karena adanya kerusakan permeabilitas membran sel dan berakhir dengan rusaknya dinding sel, sehingga berakibat keluarnya hemoglobin dari sel dan menurunkan kadar $\mathrm{Hb}$. Wresdiyati dkk,) mengemukakan bahwa Escherichia coli menyebabkan diare dengan melakukan penempelan yang sangat kuat dan menyebabkan luka pada sel epitel usus sehingga terjadi pengeluaran cairan berlebihan keusus sehingga menyebabkan diare. Mekanisme diare akibat infeksi bakteri adalah bakteri memasuki traktus digesif, lalu berkembang biak serta mengeluarkan toksik (enterotoxic) yang langsung menyerang epitel usus sehingga terjadi peningkatan aktivitas enzim adenil siklase. Dengan adanya peningkatan aktivitas enzim, maka terjadi peningkatan CAMP. ${ }^{16}$

Penambahan CAMP mengakibatkan sekresi natrium, klorida dan air dari lumen usus masuk kedalam sel. Setelah itu terjadi hiperperistaltik yang mengeluarkan cairan berlebih dari lumen usus halus ke usus besar. Jika penyerapan kolon berkurang atau sekresi cairan melebihi penyerapan kolon maka terjadi diare. Diare yang terjadi menyebabkan semua tikus putih stres yang akan mengaktifasi serotonin sehingga menyebabkan terjadinya peningkatan kerja dari HPA axis, kortisol dan gaster. Akibat dari peningkatan kerja gaster akan menyebabkan sekresi $\mathrm{HCl}$ berlebih sehingga terjadinya peningkatan asam lambung dan akan merusak kompleks heme yang berfungsi menyebabkan darah berwarna merah, dengan rusaknya kompleks heme maka pembentukan hemoglobin terlalu lambat. Penyakit diare juga mengganggu nafsu makan tikus sehingga menurunkan tingkat konsumsi gizi termasuk besi yang berperan dalam pembentukan haemoglobin jadi semakin rendah asupan zat besi dalam tubuh maka semakin rendah juga kadar haemoglobin.

Tabel 2. Kadar Haemoglobin Darah Tikus Putih setelah Diinduksi dengan E.Coli (pada Kondisi Diare)

\begin{tabular}{|c|c|c|c|c|c|}
\hline \multirow[t]{2}{*}{ Variabel } & \multirow[t]{2}{*}{$\begin{array}{l}\text { Diinduksi } d g n \\
\text { E.coli dan } \\
\text { Diberi Ferog- } \\
\text { lobin } 0,2 \mathrm{~mL}\end{array}$} & \multicolumn{4}{|c|}{$\begin{array}{c}\text { Diinduksi } d g n \text { E.coli Diberi Ekstrak Daun } \\
\text { Sambung Nyawa (mg } / \mathrm{kgBB})\end{array}$} \\
\hline & & 0,0 & 300 & 600 & 900 \\
\hline $\begin{array}{l}\text { Kadar Hb } \\
\text { (gr/dL) }\end{array}$ & $10,6 \pm 0,36$ & $10,76 \pm 0,25$ & $10,3 \pm 0,3$ & $10,16 \pm 0,15$ & $10,2 \pm 0,26$ \\
\hline
\end{tabular}


Dari analisis varians data kadar haemoglobin darah tikus putih yang telah diinduksi dengan bakteri Escherichia coli lalu diberi ekstrak daun sambung nyawa dengan dosis yang bervariasi diperoleh $\mathrm{F}_{\text {hitung }}=33,6$ sedangkan $\mathrm{F}_{\text {tabel }}$ pada taraf $1 \%=5,99$. Karena $F_{\text {hitung }} \geq F_{\text {tabel }}$ maka disimpulkan bahwa pemberian ekstrak daun sambung nyawa (Gynura procumbens (Lour.)Merr.) pada tikus putih yang telah diinduksi dengan bakteri Escherichia coli berpengaruh sangat nyata terhadap kadar haemoglobin darah. Berdasarkan hasil uji BNT diperoleh kesimpulan bahwa pemberian ekstrak daun sambung nyawa dengan dosis 900 $\mathrm{mg} / \mathrm{kg}$ BB pada tikus putih yang diinduksi dengan bakteri E,coli memberikan kadar haemoglobin yang paling tinggi.

Tabel 3. Rataan kadar haemoglobin darah tikus putih setelah diinduksi dengan escherichia coli dan diberi ekstrak daun sambung nyawa (gynura procumbens (lour.)merr.) dengan dosis yang bervariasi dan feroglobin (kontrol positip).

\begin{tabular}{|c|c|c|c|c|c|}
\hline \multirow[t]{2}{*}{ Variabel } & \multirow{2}{*}{$\begin{array}{l}\text { Diinduksi } d g n \\
\text { E.coli lalu } \\
\text { Diberi Ferog- } \\
\text { lobin } 0,2 \mathrm{~mL}\end{array}$} & \multicolumn{4}{|c|}{$\begin{array}{l}\text { Diinduksi } d g n \text { E.colil;alu Diberi Ekstrak Daun } \\
\text { Sambung Nyawa dengan dosis(mg/kgBB) }\end{array}$} \\
\hline & & 0,0 & 300 & 600 & 900 \\
\hline $\begin{array}{l}\mathrm{Kadar} H \mathrm{Hb} \\
(\mathrm{g} / \mathrm{dL})\end{array}$ & $14,1 \pm 0,52^{\mathrm{a}}$ & $10,5 \pm 0,25^{b}$ & $\begin{array}{l}11,7 \pm 0,2 \\
6^{c}\end{array}$ & $\begin{array}{l}12,3 \pm 0,4 \\
1^{\mathrm{c}}\end{array}$ & $13,7 \pm 0,61^{a}$ \\
\hline
\end{tabular}

Dari hasil uji fitokimia dalam penelitian ini diperoleh bahwa pada ekstrak etanol $96 \%$ daun sambung nyawa mengandung alkaloid, flavonoid, saponin, steroid dan tanin. Metabolit sekunder yang didapatkan memiliki aktivitas antibakteri, dapat dibuktikan dalam Penelitian Aryanti dkk, menyatakan bahwa ekstrak tanaman sambung nyawa memiliki aktivitas sebagai antibakteri. Tanaman sudah dapat dimanfaatkan sebagai antibakteri pada usia panen 4 bulan dan tanaman ini lebih aktif terhadap bakteri S.aureus dari pada E.coli dan S.typhimurium. ${ }^{2}$

Dalam penelitian Rahman dkk, bahwa flavonoid memiliki fungsi sebagai antibakteri melalui 3 mekanisme diantaranya menghambat sintesis asam nukleat, menghambat fungsi membrane sel dan menghambat metabolisme energi. Salah satu pengaruh meningkatnya kadar haemglobin darah tikus putih disebabkan karena adanya kandungan flavonoid yang terdapat dalam ekstrak karena senyawa flavonoid memiliki sifat antioksidan yang menjaga heme ion untuk produksi methamoglobin.
Flavonoid jenis quersetin dan morin berfungsi meningkatkan kadar haemoglobin dengan menghambat aktivitas enzim heme seperti cytochrome dan cylooygenase sehingga polifenol lipofilik menembus melalui membran plasma eritrosit dan mengoksidasi heme di sitoplasma dan tidak terjadi kerusakan membran eritrosit, Alkaloid juga memiliki aktivitas antibakteri yaitu dengan mengganggu komponen penyusun peptidoglikan pada sel bakteri, sehingga lapisan dinding sel tidak terbentuk secara utuh dan menyebabkan kematian sel tersebut ${ }^{17}$.

Mekanisme kerja saponin sebagai antibakteri yaitu dengan menurunkan tegangan permukaan sehingga menyebabkan naiknya permeabilitas atau kebocoran sel dan mengakibatkan senyawa intraseluler akan keluar $^{18}$. Mekanisme kerja steroid sebagai antibakteri adalah denganmerusak membran lipid, sehingga liposommengalami kebocoran serta steroid juga diketahui dapat berinteraksi dengan membran fosfolipid, karena sifatnya yang permeabel terhadap senyawasenyawa lipofilik menyebabkan integritas membran menurun dan morfologi membran sel terganggu yang mengakibatkan sel mengalami lisis dan rapuh sehingga bakteri mengalami kematian ${ }^{19}$.

Senyawa lain yang bersifat sebagai antibakteri adalah tanin, Tanin memiliki aktivitas sebagai antibakteri. Toksisitas tanin dapat merusak membran sel bakteri. Mekanisme kerja senyawa tanin dalam menghambat sel bakteri yaitu dengan cara mendenaturasi protein sel bakteri, menghambat sel bakteri yaitu dengan cara mendenaturasi protein sel bakteri, menghambat fungsi selaput sel (transport zat dari sel satu ke sel lain) dan menghambat sintesis asam nukleat sehingga pertumbuhan bakteri dapat terhambat. Tanin juga dapat membentuk komplek dengan protein dan interaksi hidrofobik, jika terbentuk ikatan hidrogen antara lain tanin dengan protein enzim yang terdapat pada bakteri maka kemungkinan akan terdenaturasi sehingga metabolisme bakteri terganggu, selain itu dengan adanya tanin (asam tanat) maka akan terjadi penghambat metabolisme sel, mengganggu sintesa dinding sel dan protein dengan menggagu aktivitas enzim ${ }^{20,21}$.

Pemeriksaan kadar hemoglobin dengan metode sianmethemoglobin memerlukan larutan drabkins yang terdiri atas kalium ferrisianida yang mengikat heme (ferro) menjadi (ferri) methemoglobin, ion sianida mengubah methemoglobin menjadi sianmethemoglobin, $\mathrm{KH}_{2} \mathrm{PO} 4$ mengatur dan 
mempertahankan pH larutan (7.0-7.4) serta non ionic detergent memiliki fungsi dalam mempercepat lisisnya eritrosit, dengan pengingkatan jumlah sel leukosit dapat mengakibatkan kekeruhan serta mengganggu pembacaan spektrofotometer.

\section{Kesimpulan}

Dari hasil penelitian yang telah dilakukan, Pemberian ekstrak daun sambung nyawa (Gynura procumbens (Lour.)Merr.)pada tikus putih yang telah diinduksi dengan bakteri Escherichia coli berpengaruh sangat nyata terhadap kadar haemoglobin darah serta Pemberian ekstrak daun sambung nyawa dengan dosis $900 \mathrm{mg} / \mathrm{kg}$ BB pada tikus putih yang diinduksi dengan bakteri E,coli memberikan kadar haemoglobin yangpaling tinggi dan tidak berbeda dengan kadar haemoglobin tikus putih yang diberi feroglobin.

\section{Referensi}

1. Sinaga, M. S., Siagian, P. D., \& Ariska, R. (2017). Pemanfaatan Ekstrak Daun Sambung Nyawa (Gynura procumbens [Lour]. Merr) Sebagai Antioksidan Pada Minyak Kelapa Menggunakan Pelarut Metanol. Jurnal Teknik Kimia USU, 6(2), pp. 41-47.

2. Aryanti, H., Syafria, Y., \& Ermayanti, T. M. (2007). Isolasi dan uji antibakteri batang sambung nyawa (Gynura procumbens(Lour) Merr) umur panen 1, 4 dan 7 bulan. Jurnal Bahan Alam Indonesia, 6(2), pp.43-45.

3. Bakhtra, D. D., Jubahar, J., \& Yusdi, E. (2018). Uji Aktivitas Fraksi Dari Ekstrak Daun Sambung Nyawa (Gynura procumbens(Lour) Merr.) Terhadap Bakteri Shigella dysenteriae. Jurnal Farmasi Higea, 10(1), pp.10-18.

4. Selviani, A., Sugito, S., \& Sutriswanto, S. (2019). Pengaruh Variasi Konsentrasi Ekstrak Daun Sambung Nyawa terhadap Zona Hambat Bakteri Escherichia coli Metode Difusi. Jurnal Laboratorium Khatulistiwa, 2(2), pp.44-48.

5. Bakri, Z., Hatta, M., \& Massi, M. N. (2015). Deteksi keberadaan bakteri Escherichia coli O157: H7 pada feses penderita diare dengan metode kultur dan PCR. Jst Kesehatan, 5(2), pp.184-192.

6. Sackey, M. E., Weigel, M. M., \& Armijos, R. X. (2003). Predictors And Nutritional Consequences Of Intestinal Parasitic Infections In Rural Ecuadorian Children. Journal Of Tropical Pediatrics, 49(1), pp.17-23.

7. Guyton, A. C. (1987). Renal function curve--a key to understanding the pathogenesis of hypertension. Hypertension, 10(1), pp.1-6.
8. Agustina, S., Ruslan, R., \& Wiraningtyas, A. (2016). Skrining fitokimia tanaman obat di kabupaten Bima. Cakra Kimia (Indonesian EJournal of Applied Chemistry), 4(1), pp.71-76.

9. Meigaria, K. M., Mudianta, I. W., \& Martiningsih, N. W. (2017). Skrining fitokimia dan uji aktivitas antioksidan ekstrak aseton daun kelor (Moringa oleifera). Wahana Matematika dan Sains: Jurnal Matematika, Sains, dan Pembelajarannya, 10(2), pp.1-11.

10. Supriningrum, R., Handayani, F. \& Liya, L. (2017). Karakterisasi dan Skrining Fitokimia Daun Singkil (Premna corymbosa Rottl \& Willd). Jurnal Ilmiah Ibnu Sina, 2(2), pp.232 244.

11. Shevla,.(1990).Buku Teks Analisis Anorganik Kualitatif Makro dan Semimikro, Edisi ke-1.

12. Ergina, E., Nuryanti, S., \& Pursitasari, I. D. (2014). Uji kualitatif senyawa metabolit sekunder pada daun palado (Agave angustifolia) yang diekstraksi dengan pelarut air dan etanol. Jurnal Akademika Kimia, 3(3), pp.165-172.

13. Simaremare, E. S. (2014). Skrining fitokimia ekstrak etanol daun gatal (Laportea decumana (Roxb.) Wedd). PHARMACY: Jurnal Farmasi Indonesia (Pharmaceutical Journal of Indonesia), 11(1),pp.98-107.

14. Marliana, S. D., Suryanti, V., \& Suyono, S. (2005). The Phytochemical Screenings And Thin Layer Chromatography Analysis Of Chemical Compounds In Ethanol Extract Of Labu Siam Fruit (Sechium Edule Jacq. Swartz.). Biofarmasi Journal of Natural Product Biochemistry, 3(1), pp.26-31.

15. Marliana, S.D., Saleh, C. (2011). Uji Fitokimia dan Aktivitas Antibakteri Ekstrak Kasar Etanol, Fraksi nHeksana, Etil asetat, dan Metanol dari Buah Labu Air (Lagenari siceraria (Morliana). J. Kimia Mulawarman, 8(2), pp.39-63

16. Wresdiyati, T., Laila, S. R., Setiorini, Y., Arief, I. I., \& Astawan, M. (2013). Probiotik Indigenus Meningkatkan Profil Kesehatan Usus Halus Tikus yang Diinfeksi Enteropathogenic E. coli. Majalah Kedokteran Bandung, 45(2), pp.7885.

17. Rahman, F. A., Haniastuti, T., \& Utami, T. W. (2017). Skrining Fitokimia Dan Aktivitas Antibakteri Ekstrak Etanol Daun Sirsak (Annona Muricata L.) Pada Streptococcus Mutans ATCC 35668. Majalah Kedokteran Gigi Indonesia, 3(1), pp. 1-7.

18. Nursidika, P., Saptarini, O., \& Rafiqua, N. (2014). Aktivitas antimikrob fraksi ekstrak etanol buah pinang (Areca catechu L) pada bakteri Methicillin resistant Staphylococcus aureus. Majalah Kedokteran Bandung, 46(2), pp. 94-99. 
19. Siregar, D.R. \& Silitonga, P.M. (2020, Dec.). "The Effect of Sambung Nyawa Leaf Extract (Gynura Procumbens) on Albumin and Globulin of Rats (Rattus Novergicus) Serum Induced by E. Coli Bacteria". Indonesian Journal of Chemical Science and Technology. 4(1), pp. 2933.

20. Madduluri, Suresh. Rao, K.Babu. Sitaram, B. (2013). In Vitro Evaluation of Antibacterial Activity of Five Indegenous Plants Extract Against Five Bacterial Pathogens of Human. International Journal of Pharmacy and Pharmaceutical Sciences. 5(4), pp. 679-684.

21. Simorangkir, M. \& Maha, A.P. (2020, July). "Antibacterial Activity and Phytochemical Screening from Chromatography Fraction of Ethanol Extract of Sarang Banua (Clerodendum fragrans Vent Willd) against Salmonella enterica". Indonesian Journal of Chemical Science and Technology. 3(2), pp. 42-48 